\title{
Supplementation with Extruded Linseed Cake Affects Concentrations of Conjugated Linoleic Acid and Vaccenic Acid in Goat Milk
}

\author{
A. Nudda, G. Battacone, M. G. Usai, ${ }^{1}$ S. Fancellu, and G. Pulina ${ }^{2}$ \\ Dipartimento di Scienze Zootecniche, Universitá degli Studi di Sassari, 07100 Sassari, Italy
}

\begin{abstract}
The aim of this research was to determine the effect of adding extruded linseed cake to the dry diet of goats on the concentrations of conjugated linoleic acid (CLA) and vaccenic acid (VA) in milk fat. Thirty crossbreed dairy goats were divided into 3 groups. Their diet was supplemented with 0\% (control group), 5\% (low group), or $10 \%$ (high group) of extruded linseed cake (ELC), which supplied 0,16 , and $32 \mathrm{~g} / \mathrm{d}$ of linseed fat, respectively. The milk fat percentage (overall mean 3.5\%) and yield did not differ with the different diets, but fatty acid composition was affected by the ELC supplements. The inclusion of ELC in the diets did not influence the concentration of fatty acids from C6:0 to C12:0. The concentrations of C14:0 and C16:0 decreased as the quantity of ELC supplements increased. The concentrations $(\mathrm{mg} / 100 \mathrm{mg}$ of total fatty acid methyl esters) of VA $(0.70,1.23$, and 1.39 in control, low, and high groups respectively) and cis-9,trans-11 CLA $(0.63,0.96$, and 1.05 in control, low, and high groups, respectively) were increased by ELC supplements. The milk fat content of VA and cis-9, trans-11 CLA were closely correlated $\left(R^{2}=0.82\right)$. Desaturation of VA in the mammary gland to produce cis-9,trans-11 CLA was higher in the control group than in the groups with ELC diets. Extruded linseed cake supplementation to lactating goats may enhance the nutritional profile of milk lipids.
\end{abstract}

Key words: linseed, goat milk, conjugated linoleic acid, vaccenic acid

\section{INTRODUCTION}

Dairy products are the main dietary source of conjugated linoleic acid (CLA). Among the individual CLA isomers, the greatest attention has been focused on cis9,trans-11 and trans-10,cis-12 CLA. The cis-9,trans-11 CLA is thought to have anticarcinogenic properties and makes up approximately 75 to $85 \%$ of the CLA in the

Received January 20, 2005.

Accepted September 20, 2005.

${ }^{1}$ Current address: Istituto Zootecnico e Caseario per la Sardegna, Loc. Bonassai, 07040, Italy.

${ }^{2}$ Corresponding author: gpulina@uniss.it milk fat of cows (Piperova et al., 2004) and 78 to $89 \%$ of the CLA in the milk fat of sheep (Antongiovanni et al., 2004). The trans-10,cis-12 CLA isomer is mainly involved in lipid metabolism and has been shown to reduce milk fat in cows (Baumgard et al., 2000) and body fat in mice (DeLany et al., 1999) and humans (Blankson et al., 2000). Recently, some experiments on laboratory animals appear to suggest that the trans10 ,cis-12 isomer may have detrimental effects on health (Wahle et al., 2004). However, the trans-10,cis-12 CLA content in dairy products is very low, accounting for less than $1.5 \%$ of total CLA (Antongiovanni et al., 2004; Loor et al., 2005). The cis-9,trans-11 CLA in milk fat is produced either as an intermediate during the rumen biohydrogenation of linoleic acid or in the mammary gland by $\Delta^{9}$-desaturase from vaccenic acid (VA; trans11 C18:1), another intermediate in ruminal biohydrogenation (Griinari et al., 2000). The conversion of VA into cis-9,trans-11 CLA has also been observed in the tissue of humans (Adlof et al., 2000).

Diet is the main factor that influences milk CLA and VA concentrations; the highest content of both fatty acids (FA) was found in the milk of cows and sheep grazing on pasture and in those fed diets supplemented with unsaturated oil. Supplementation with plant oils and seeds such as soybean, sunflower, peanut (high linoleic acid), and linseed (high linolenic acid) produced milk with higher VA and CLA contents (Dhiman et al., 2000; Secchiari et al., 2003). An increase of CLA and VA in milk fat was also obtained in experiments that used olive oil (Secchiari et al., 2003) and Canola oil (Chouinard et al., 2001) as supplements for dairy cow diets.

Mir et al. (1999) reported a marked increase of milk CLA content in goats supplemented with Canola oil. Chilliard et al. (2003) observed a substantial increase in the VA and CLA content in the milk fat of goats given dietary supplements of free oil from linseed or sunflowers. The use of free oil higher than $2 \%$ of the diet is not recommended, because it inhibits rumen microbial activity (Jenkins, 1993). The whole crude oilseeds were not as efficient as free linseed or sunflower oils in increasing VA and CLA in goat milk fat (Chilliard et al., 2003). In cows, the use of heat-treated oilseeds 
NUDDA ET AL.

Table 1. Ingredients, chemical composition, and fatty acid (FA) profiles of the diets

\begin{tabular}{|c|c|c|c|}
\hline & \multicolumn{3}{|c|}{$\operatorname{Diet}^{1}$} \\
\hline & Control & Low & High \\
\hline \multicolumn{4}{|l|}{ Ingredients, $\%$} \\
\hline Commercial mix $^{2}$ & 74 & 74 & 74 \\
\hline Concentrate $^{3}$ & 16 & 16 & 16 \\
\hline $\mathrm{ELC}^{4}$ & - & 5 & 10 \\
\hline Peas $^{5}$ & 10 & 5 & - \\
\hline \multicolumn{4}{|l|}{ Chemical composition } \\
\hline DM, \% & 88.8 & 88.9 & 89.3 \\
\hline $\mathrm{CP}, \%$ of $\mathrm{DM}$ & 17.5 & 17.9 & 18.3 \\
\hline $\mathrm{NDF}, \%$ of DM & 38.5 & 38.6 & 38.7 \\
\hline $\mathrm{ADF}, \%$ of $\mathrm{DM}$ & 21.8 & 22.1 & 22.5 \\
\hline Acid detergent lignin, \% of DM & 4.1 & 4.5 & 4.9 \\
\hline Ash, \% of DM & 7.7 & 7.8 & 8.0 \\
\hline Lipid extract, \% of DM & 2.4 & 3.1 & 3.9 \\
\hline \multicolumn{4}{|c|}{$\begin{array}{l}\text { Fatty acid, mg/100 mg of total FA methyl esters } \\
\text { C14:0 }\end{array}$} \\
\hline C16:0 & 13.5 & 13.2 & 12.9 \\
\hline C18:0 & 3.5 & 3.5 & 3.5 \\
\hline C18:1 & 19.0 & 18.7 & 18.5 \\
\hline $\mathrm{C} 18: 2$ cis-9,cis-12 & 42.6 & 41.2 & 39.8 \\
\hline C18:3 n-3 & 5.5 & 7.8 & 10.1 \\
\hline
\end{tabular}

${ }^{1}$ High $=10 \%$ extruded linseed cake (ELC, Linopiù-Cortal); Low $=5 \%$ ELC; Control = 0\% ELC.

${ }^{2}$ Commercial mix: alfalfa hay, corn meal, soybean hull, beet pulp, sunflower meal, wheat bran, flaked corn, barley, soybean meal, cane molasses, vitamins (A 6,600 IU/kg, $\mathrm{D}_{3} 600 \mathrm{IU} / \mathrm{kg}, \mathrm{B}_{3} 6 \mathrm{mg} / \mathrm{kg}$, and E 12 $\mathrm{mg} / \mathrm{kg}$ ) and minerals supplement (Zn $46.8 \mathrm{mg} / \mathrm{kg}$ and $\mathrm{Mn} 24.8 \mathrm{mg} / \mathrm{kg}$ ).

${ }^{3}$ Concentrate: corn, barley, and beet pulp.

${ }^{4}$ The percentages of the main FA in ELC fat was: C16:0 = 6.0; C18:0 = 3.5; C18:1 = 19.5; C18:2 = 16.1; and $\mathrm{C} 18: 3=52.2$.

${ }^{5}$ The percentages of the main FA in peas fat was: $\mathrm{C} 16: 0=12.7 ; \mathrm{C} 18: 0=4.2 ; \mathrm{C} 18: 1=25.8 ; \mathrm{C} 18: 2=44.2$; and $\mathrm{C} 18: 3=7.0$.

(e.g., extruded oilseeds) have shown a positive influence on VA and CLA concentration in milk fat compared with raw oilseed (Chouinard et al., 1997; Dhiman et al., 2000). The aim of our work was to investigate whether extruded linseed cake (ELC) would be a suitable supplement to enhance CLA and VA contents in milk fat of goats fed a dry diet.

\section{MATERIALS AND METHODS}

\section{Animals and Treatments}

Thirty lactating crossbreed goats (Alpine $\times$ Sarda) milked twice a day were randomly assigned to 1 of 3 experimental groups. The animals (DIM >150) were fed $2 \mathrm{~kg} / \mathrm{d}$ comprising $1.8 \mathrm{~kg}$ of a TMR and $200 \mathrm{~g}$ of supplement (Table 1). The TMR ( $89 \%$ of DM) contained a fibrous commercial mix [18\% CP, $2.5 \%$ ether extract, $41 \% \mathrm{NDF}, 25.5 \% \mathrm{ADF}, 5.4 \%$ acid detergent lignin (ADL)], and a concentrate composed of corn, barley, and beet pulp ( $11 \% \mathrm{CP}, 2.2 \%$ ether extract, $33.5 \% \mathrm{NDF}$, $12.7 \% \mathrm{ADF}, 1.1 \% \mathrm{ADL}$ ). The supplement was $0 \mathrm{~g}$ (control), $100 \mathrm{~g}$ (low diet), or $200 \mathrm{~g}$ (high diet) of ELC (Linopiù-Cortal, Cortal S.p.a., Padova, Italy; 95\% DM, $27.8 \% \mathrm{CP}, 16.9 \%$ ether extract, $29.3 \% \mathrm{NDF}, 15.5 \% \mathrm{ADF}$,
7.3\% ADL), which supplied 0 (control), 16 (low), and 32 $\mathrm{g} / \mathrm{d}$ (high) of linseed fat, respectively.

The ELC was obtained by dry extrusion of whole linseed at $155^{\circ} \mathrm{C}$ before oil extraction by mechanical press. The CP content of the 3 diets (18\% of DM) was kept at similar level by adding 200 and $100 \mathrm{~g}$ of peas (89\% DM, $25.7 \% \mathrm{CP}, 1.6 \%$ ether extract, $28.4 \% \mathrm{NDF}$, $8.7 \% \mathrm{ADF}, 0.02 \% \mathrm{ADL}$ ) to the control and low diets, respectively. Goats were fed a diet formulated to meet their energy requirements (INRA, 1989). Samples of dietary ingredients were collected once before the beginning of the experiment to determine DM and for chemical analysis. The trial lasted $21 \mathrm{~d}$, which included $12 \mathrm{~d}$ for adaptation and $9 \mathrm{~d}$ for data collection. Milk yield was recorded and milk samples were collected twice a day at each milking at 3 -d intervals. One aliquot of milk samples was analyzed for milk fat and total protein and another aliquot was stored at $-20^{\circ} \mathrm{C}$ for subsequent FA analysis.

\section{Feed and Milk Analyses}

The DM content of the feed was determined by ovendrying at $105^{\circ} \mathrm{C}$ for $24 \mathrm{~h}$. Dried feed samples were ana- 
lyzed for NDF, ADF, and ADL with the procedure of Van Soest et al. (1991) by using the filter bag equipment of Ankom (Ankom Technology Corp., Fairport, NY), ash (AOAC, 2000; method 942.05), CP (AOAC, 2000; method 988.05) and fat (Folch et al., 1957). Chemical analyses were expressed as percentages of DM. The fat and total protein of individual milk samples of a.m. and p.m. milkings were determined using a FIL-IDF procedure (2000), with a Milkoscan-6000 (A.R.A. Sardegna laboratory, Oristano, Italy). The milk samples of a.m. and p.m. milkings were composited in a daily sample to determine milk FA composition, including CLA and VA.

Milk fat extraction and fatty acid methyl esters (FAME) preparation were performed as detailed by Nudda et al. (2005). The FAME were separated on a capillary column (CB-Fame CP-select; $100 \mathrm{~m} \times 0.32 \mathrm{~mm}$ i.d., 0.25- $\mu \mathrm{m}$ film thickness, Varian Inc., Palo Alto, CA). The injector and flame-ionization detector temperatures were $255^{\circ} \mathrm{C}$. The programmed temperature was $75^{\circ} \mathrm{C}$ for $1 \mathrm{~min}$. It was then increased to $165^{\circ} \mathrm{C}$ at a rate of $8^{\circ} \mathrm{C} / \mathrm{min}$, and maintained for $35 \mathrm{~min}$, increased to $210^{\circ} \mathrm{C}$ at a rate of $5.5^{\circ} \mathrm{C} / \mathrm{min}$, and finally increased to $240^{\circ} \mathrm{C}$ at a rate of $15^{\circ} \mathrm{C} / \mathrm{min}$. The split ratio was $1: 40$ with $\mathrm{He}$ at a pressure of $2.55 \mathrm{bar}$ as the carrier gas. Individual FAME were identified by comparing the relative retention times of FAME peaks from samples, using the standards mixture (37 Component FAME Mix, Supelco, Bellefonte, PA). The standards PUFA-2, nonconjugated 18:2 isomer mixture, and individual cis5,8,11,14,17 C20:5, cis-4,7,10,13,16,19 C22:6 (Supelco), cis-6,9,12 C18:3, and cis-9,12,15 C18:3 (Matreya Inc., Pleasant Gap, PA) were used to identify polyunsaturated fatty acids. High-purity individual CLA cis9,trans-11 and trans-10,cis-12 (Matreya Inc.) were used. Verification of other CLA peaks was done using a commercially available CLA standard mix (Nu-Chek Prep, Inc., Elysian, MN). Individual trans-9 C18:1 and trans-11 C18:1 (Supelco) were used to identify trans C18:1 isomers. The isomer trans-10 C18:1 was not available commercially. Therefore, the trans C18:1 isomers reported were identified by order of elution as described by Griinari et al. (1998). The relative amount of each FAME was quantified by integrating the area under the peak and dividing the result by the total area for all FA. The internal standard (C19:0) was used to convert peak area percentage to weight percentage $(\mathrm{mg} /$ $100 \mathrm{mg}$ of total FAME). Fatty acids of feed lipid extract were esterified using the procedure described by Palmquist and Jenkins (2003) and determined under the same chromatography conditions as those for milk FA. The FA composition of the experimental diets was calculated from the FA composition of the individual dietary ingredients. The ratio [cis-9,trans-11 CLA $] /[c i s-$ 9,trans-11 CLA + VA], as an indirect measurement of $\Delta^{9}$-desaturase activity in the mammary gland, was calculated separately for each experimental group.

Data were analyzed with the following mixed linear model according to a repeated measures design (Littell et al., 1998):

$$
\mathrm{Y}_{\mathrm{ijkl}}=\mu+\mathrm{D}_{\mathrm{i}}+\mathrm{P}_{\mathrm{j}}+(\mathrm{D} \times \mathrm{P})_{\mathrm{ij}}+\mathrm{A}_{\mathrm{k}}(\mathrm{i})+\varepsilon_{\mathrm{ijkl}}
$$

where $Y_{i j k l}=$ observation (milk, fat and protein yields, fat and protein contents, FAME), $\mu=$ overall mean, $D_{i}=$ fixed effect of diet $i(i=3), P_{j}=$ fixed effect of the period $\mathrm{j}(\mathrm{j}=3),(\mathrm{D} \times \mathrm{P})_{\mathrm{ij}}=$ interaction between diet and period, $\mathrm{A}_{\mathrm{k}}(\mathrm{i})=$ random effect of animal $\mathrm{k}(\mathrm{k}=30)$ nested within diet $\mathrm{i}$, and $\varepsilon_{\mathrm{ijkl}}=$ random residual. The effect of the diet was tested by using the variance associated with animal within treatment as error term. Pairwise comparisons among means were performed using the Tukey test. Differences were declared significant at $P \leq 0.05$.

\section{RESULTS AND DISCUSSION}

Ingredients, chemical composition, and FA profile of the experimental diets are reported in Table 1. Addition of ELC increased the total lipid content in the high and low groups compared with the control group. Because ELC contained $16.9 \%$ of lipids, and linolenic acid represented $52.2 \%$ of the FA in the extracted lipids, including ELC in the diets caused a linear increase of C18:3 FA.

Milk production traits and the FA profile of milk fat are reported in Table 2. Milk yield, fat and protein content, and fat and protein yield were not influenced by the addition of ELC to the diets. Although fat supplements in the diets of dairy cows (Chilliard et al., 2003) and sheep (Nudda et al., 2004) often decrease milk protein content, this was not the case in this study, which agrees with the results of previous studies on goats (Chilliard et al., 2003).

The inclusion of ELC in the diets did not influence the concentration of FA from $\mathrm{C} 6: 0$ to $\mathrm{C} 12: 0$, whereas it reduced the concentrations of $\mathrm{C} 14: 0, \mathrm{C} 16: 0$, and C16:1. The content of $\mathrm{C} 16: 0$ in milk originates both from de novo synthesis in the mammary gland and from uptake from arterial blood. In the ELC groups, the reduction of C16:0 is probably due to decreased synthesis in the mammary gland, because the dietary levels of C16:0 were similar in all diets. A similar trend has been observed with other oil sources (Chilliard et al., 2003). In terms of human health, the decrease of C14:0 and C16:0 represents an improvement in the FA profile of milk because of the potential effects of these FA in cholesterol-raising activity (Kris-Etherton and Yu, 1997). The ELC supplements increased significantly the concentrations of C18:0, cis-9 C18:1, and C18:3 n-3 in milk 
Table 2. Milk yield, composition, and fatty acids (FA) profile of milk from goats fed diets containing extruded linseed cake (ELC)

\begin{tabular}{|c|c|c|c|c|}
\hline & \multicolumn{3}{|c|}{$\operatorname{Diet}^{1}$} & \multirow[b]{2}{*}{$\mathrm{SE}$} \\
\hline & Control & Low & High & \\
\hline Milk, g/d & 1,188 & 1,039 & 1,138 & 111.4 \\
\hline Fat, $\%$ & 3.37 & 3.50 & 3.55 & 0.167 \\
\hline Fat, g/d & 39.90 & 35.45 & 38.72 & 3.138 \\
\hline Total protein, \% & 2.86 & 2.84 & 3.00 & 0.130 \\
\hline Total protein, g/d & 33.79 & 28.98 & 33.32 & 2.806 \\
\hline \multicolumn{5}{|l|}{$\begin{array}{l}\text { Fatty acid, mg/100 mg } \\
\text { total FA methyl esters }\end{array}$} \\
\hline $\mathrm{C} 6: 0$ & 1.58 & 1.46 & 1.59 & 0.068 \\
\hline $\mathrm{C} 8: 0$ & 2.01 & 1.87 & 2.05 & 0.104 \\
\hline C10:0 & 8.23 & 7.40 & 7.77 & 0.387 \\
\hline $\mathrm{C} 12: 0$ & 3.93 & 3.48 & 3.67 & 0.281 \\
\hline C14:0 & $10.68^{\mathrm{a}}$ & $9.81^{b}$ & $9.46^{\mathrm{b}}$ & 0.323 \\
\hline C14:1 & 0.22 & 0.18 & 0.17 & 0.017 \\
\hline C16:0 & $35.88^{\mathrm{a}}$ & $32.40^{\mathrm{b}}$ & $27.50^{\mathrm{b}}$ & 1.482 \\
\hline C16:1 & $0.93^{\mathrm{a}}$ & $0.77^{\mathrm{b}}$ & $0.70^{\mathrm{b}}$ & 0.047 \\
\hline $\mathrm{C} 18: 0$ & $6.91^{\mathrm{b}}$ & $8.74^{\mathrm{a}}$ & $10.01^{\mathrm{a}}$ & 0.535 \\
\hline C18:1 trans $-6-8$ & $0.18^{b}$ & $0.25^{\mathrm{a}}$ & $0.28^{\mathrm{a}}$ & 0.016 \\
\hline C18:1 trans -9 & $0.19^{b}$ & $0.26^{\mathrm{a}}$ & $0.26^{\mathrm{a}}$ & 0.012 \\
\hline C18: 1 trans -10 & 0.26 & 0.30 & 0.29 & 0.032 \\
\hline C18:1 trans-11 (vaccenic acid) & $0.70^{\mathrm{b}}$ & $1.23^{\mathrm{a}}$ & $1.39^{\mathrm{a}}$ & 0.130 \\
\hline $\mathrm{C} 18: 1$ trans -12 & 0.21 & 0.39 & 0.23 & 0.048 \\
\hline C18:1 cis-9 & $18.54^{\mathrm{b}}$ & $20.72^{\mathrm{a}}$ & $23.50^{\mathrm{a}}$ & 1.091 \\
\hline $\mathrm{C} 18: 2$ cis $-9, c i s-12$ & 2.36 & 2.44 & 2.44 & 0.124 \\
\hline C18:3 n-6 & 0.09 & 0.08 & 0.08 & 0.004 \\
\hline C18:3 n-3 & $0.45^{\mathrm{c}}$ & $0.80^{\mathrm{b}}$ & $0.99^{\mathrm{a}}$ & 0.050 \\
\hline Conjugated linoleic acid (CLA) cis-9,trans-11 & $0.63^{\mathrm{b}}$ & $0.96^{\mathrm{a}}$ & $1.05^{\mathrm{a}}$ & 0.040 \\
\hline CLA trans-10,cis-12 & $0.0004^{\mathrm{b}}$ & $0.0026^{\mathrm{a}}$ & $0.0029^{\mathrm{a}}$ & 0.001 \\
\hline CLA total ${ }^{2}$ & $0.90^{\mathrm{b}}$ & $1.26^{\mathrm{a}}$ & $1.33^{\mathrm{a}}$ & 0.042 \\
\hline C20:5 n-3 EPA ${ }^{3}$ & $0.063^{\mathrm{b}}$ & $0.077^{\mathrm{a}}$ & $0.078^{\mathrm{a}}$ & 0.006 \\
\hline C22:6 n-3 DHA ${ }^{4}$ & 0.039 & 0.045 & 0.041 & 0.004 \\
\hline CLA desaturase index ${ }^{5}$ & $0.48^{\mathrm{a}}$ & $0.45^{\mathrm{b}}$ & $0.44^{\mathrm{b}}$ & 0.007 \\
\hline
\end{tabular}

${ }^{\mathrm{a}-\mathrm{c}}$ Means within a row with different superscripts differ $(P<0.05)$.

${ }^{1}$ High $=10 \%$ ELC (Linopiù-Cortal), Low $=5 \%$ ELC; Control $=0 \%$ ELC.

${ }^{2}$ CLA total includes C20:0 and C20:1 that eluted in CLA region. The isomers have been summed because the chromatographic conditions were not adequate to allow accurate individual quantification.

${ }^{3} \mathrm{EPA}=$ Eicosapentaenoic acid.

${ }^{4} \mathrm{DHA}=$ Docosahexaenoic acid.

${ }^{5}$ Desaturase index calculated as [cis-9,trans-11 CLA $] /[$ cis-9,trans-11 CLA + VA] ratio.

fat, but did not influence the cis-9,cis-12 C18:2 content. The content of $\mathrm{C} 18: 3 \mathrm{n}-3$, which contributes to preventing atherosclerosis in humans (Kris-Etherton and $\mathrm{Yu}, 1997)$, increased by $78 \%$ in the low group and $120 \%$ in the high group $(P<0.01)$ compared with the control group.

The total CLA concentration (Table 2) was significantly affected by ELC supplements and the isomer cis9,trans-11 accounted for $77 \%$ of total CLA in the milk fat of the ELC groups and $70 \%$ in the control group. However, the proportion could be an underestimate due to the elution of $\mathrm{C} 20: 0$ and C20:1 in the CLA region under these chromatographic conditions (Nudda et al., 2005).

The concentration of cis-9,trans-11 CLA increased by 52 and $67 \%(P<0.01)$, respectively, in the low and high groups. The extent of increase in cis-9,trans-11 CLA by using ELC was higher than that observed in goats by Chilliard et al. (2003) when they used whole crude linseed supplements, but lower than their results using free linseed oil. Studies on cows found that adding heatprocessed oilseed (i.e., soybean and cottonseed) to the diet increases the CLA content in milk to a greater extent than raw oilseed supplements (Chouinard et al., 1998). This is probably due to less interaction with rumen bacteria. It is worth pointing out that the amount of trans-10,cis-12, which is thought to be detrimental to human health (Wahle et al., 2004), was about $0.3 \%$ of total CLA and was not detected in $60 \%$ of individual samples. The content of trans-10,cis-12 isomer in total CLA was the same as that found in sheep milk when different diets were used (Antongiovanni et al., 2004).

The trans C18:1 isomers were significantly affected by the supplements, with the exception of trans-10 and 


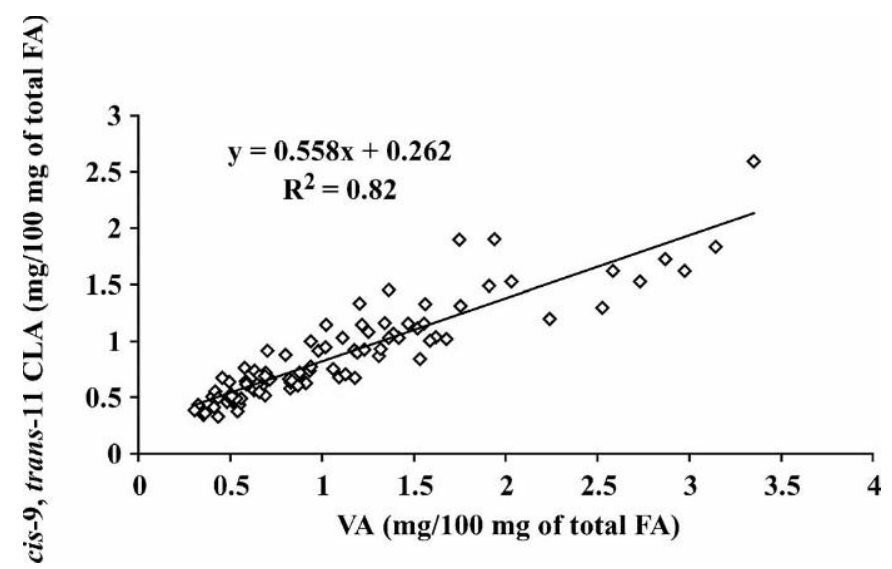

Figure 1. Relationship between cis-9,trans-11 conjugated linoleic acid (CLA) and vaccenic acid (VA) in milk from goats fed diets containing extruded linseed cake. FA = Fatty acids.

trans-12 C18:1. The relative quantity of VA increased by 76 and $99 \%(P<0.01)$ in low and high groups, respectively, compared with the control group. Chilliard et al. (2003) did not observe increases in the VA of the milk fat of goats given whole linseed supplements, but found an increase of $123 \%$ when free linseed oil was used.

A close relationship between cis-9,trans-11 CLA and VA was found in milk (Figure 1). This is consistent with the predominant origin of this CLA isomer in the mammary gland from VA via $\Delta^{9}$-desaturase. The linolenic acid supplied by ELC is a direct precursor of the VA produced in the rumen. This is transported to the mammary gland where is used for endogenous synthesis of CLA by $\Delta^{9}$-desaturase (Griinari et al., 2000; Piperova et al., 2002). The amount of desaturation, estimated from the ratio $[$ cis-9,trans-11 CLA $] /[$ cis-9,trans11 CLA + VA] as an indirect index of $\Delta^{9}$-desaturase activity, was higher in the control group than in the groups given ELC supplements. This indicates that less of the substrate FA is desaturated when goats were fed ELC diets. The polyunsaturated fatty acids content in various tissues has been found to reduce the expression of $\Delta^{9}$-desaturase (Sessler and Ntambi, 1998). The higher concentration of $\mathrm{C} 18: 3$ in the mammary glands of goats fed ELC may have decreased the $\Delta^{9}$-desaturase activity. In addition, C18:0 is the preferred substrate for $\Delta^{9}$-desaturase in the mammary gland (Chilliard et al., 2000; Mosley and McGuire, 2003). Indeed, a close negative correlation was found between the C18:0 concentration in milk and the CLA desaturase index $(\mathrm{r}=$ -0.83 ). This suggests that there is fierce competition for desaturase activity at substrate level.

The eicosapentaenoic acid (C20:5 n-3) and docosahexaenoic acid (C22:6 n-3) contents were extremely low, as is typical in the milk of ruminant species. This may be explained in part by the high amount of biohydrogenation of these FA in the rumen (Chikunya et al., 2004), and partly by the low elongation and desaturation of $\mathrm{C} 18$ and C20 FA in the mammary gland of ruminants (Gulati et al., 2003).

The concentration of almost all FA was not significantly affected by the amount of ELC supplement. Whether the linseed oil supplements were 16 or $32 \mathrm{~g} /$ $\mathrm{d}$, the milk fat CLA and VA of the goats used in this trial did not change. The lack of differences between the 2 doses of ELC on CLA and VA concentrations could be due to a threshold effect for uptake of these FA by the mammary gland. This is supported by the results of Schmidely and Morand-Fehr (2004), who observed no change in CLA content in goat's milk after intravenous infusion of CLA.

\section{CONCLUSIONS}

The supplement of ELC in the ration of dairy goats did not change the milk fat percentage and yield, but markedly influenced the fatty acid profile of the milk fat. The ELC increased the VA, cis-9,trans-11 CLA, and C18:3 n-3 contents. The ELC supplements also decreased the content of $\mathrm{C} 14: 0$ and $\mathrm{C} 16: 0$, which are known to be hypercholesterolemic in humans. The study showed that the nutritional quality of lipids in goat might be enhanced by dietary manipulation. Under our experimental conditions, the addition of $16 \mathrm{~g} /$ $\mathrm{d}$ of linseed fat in the form of extruded cake was effective in changing the fatty acid profile of milk fat in goats from a dietary and functional point of view.

\section{ACKNOWLEDGMENTS}

This research was funded by the FISR Project of the Ministero dell'Università e della Ricerca Scientifica e Tecnologica (MIUR, Italy; Italian Ministry of Education, University and Research). We wish to thank Salvatore Mulas and Roberto Rubattu for their assistance.

\section{REFERENCES}

Adlof, R. O., S. Duval, and E. A. Emken. 2000. Biosynthesis of conjugated linoleic acid in humans. Lipids 35:131-135.

Antongiovanni, M., M. Mele, A. Buccioni, F. Petacchi, A. Serra, M. P. Melis, L. Cordeddu, S. Banni, and P. Secchiari. 2004. Effect of forage/concentrate ratio and oil supplementation on C18:1 and CLA isomers in milk fat from Sarda ewes. J. Anim. Feed Sci. 13(Suppl.1):669-672.

AOAC. 2000. Official Methods of Analysis. 17th ed. Association of Official Analytical Chemists, Arlington, VA.

Baumgard, L. H., B. A. Corl, D. A. Dwyer, A. Sæbø, and D. E. Bauman. 2000. Identification of the conjugated linoleic acid isomer that inhibits milk fat synthesis. Am. J. Physiol. Regul. Integr. Comp. Physiol. 278:R179-R184.

Blankson, H., J. A. Stakkestad, H. Fagertun, E. Thom, J. Wadstein, and O. Gudmundsen. 2000. Conjugated linoleic acid reduces body 
fat mass in overweight and obese humans. J. Nutr. 130:29432948.

Chikunya, S., G. Demirel, M. Enser, J. D. Wood, R. G. Wilkinson, and L. A. Sinclair. 2004. Biohydrogenation of dietary n-3 PUFA and stability of ingested vitamin $\mathrm{E}$ in the rumen, and their effects on microbial activity in sheep. Br. J. Nutr. 91:539-550.

Chilliard, Y., A. Ferlay, R. M. Mansbridge, and M. Doreau. 2000. Ruminant milk fat plasticity: Nutritional control of saturated, polyunsaturated, trans and conjugated fatty acids. Ann. Zootech. 49:181-205.

Chilliard, Y., A. Ferlay, J. Rouel, and G. Lamberet. 2003. A review of nutritional and physiological factors affecting goat milk lipid synthesis and lipolysis. J. Dairy Sci. 86:1751-1770.

Chouinard, P. Y., L. Corneau, W. R. Butler, Y. Chilliard, J. K. Drackley, and D. E. Bauman. 2001. Effect of dietary lipid source on conjugated linoleic acid concentrations in milk fat. J. Dairy Sci. 84:680-690.

Chouinard, P. Y., V. Girard, and G. J. Brisson. 1997. Performances and profiles of milk fatty acids of cows fed full fat, heat-treated soybeans using various processing methods. J. Dairy Sci. 80:334-342.

Chouinard, P. Y., V. Girard, and G. J. Brisson. 1998. Fatty acid profile and physical properties of milk fat from cows fed calcium salts of fatty acids with varying unsaturation. J. Dairy Sci. 81:471-481.

DeLany, J. P., F. Blohm, A. A. Truett, J. A. Scimeca, and D. B. West. 1999. Conjugated linoleic acid rapidly reduces body fat content in mice without affecting energy intake. Am. J. Physiol. Regul. Integr. Comp. Physiol. 276:R1172-R1179.

Dhiman, T. R., L. D. Satter, M. W. Pariza, M. P. Galli, K. Albright, and M. X. Tolosa. 2000. Conjugated linoleic acid (CLA) content of milk from cows offered diets rich in linoleic and linolenic acid. J. Dairy Sci. 83:1016-1027.

Folch, J., M. Less, and G. H. Sloane-Stanley. 1957. A simple method for isolation and purification of total lipids from animal tissues. J. Biol. Chem. 226:497-509.

Griinari, J. M., B. A. Corl, S. H. Lacy, P. Y. Chouinard, K. V. Nurmela, and D. E. Bauman. 2000. Conjugated linoleic acid is synthesized endogenously in lactating dairy cows by Delta(9)-desaturase. J. Nutr. 130:2285-2291.

Griinari, J. M., D. A. Dwyer, M. A. McGuire, D. E. Bauman, D. L. Palmquist, and K. V. Nurmela. 1998. Trans-octadecenoic acids and milk fat depression in lactating dairy cows. J. Dairy Sci. 81:1251-1261.

Gulati, S. K., S. McGrath, P. C. Wynn, and T. W. Scott. 2003. Preliminary results on the relative incorporation of docosahexaenoic and eicosapentaenoic acids into cows milk from two types of rumenprotected fish oil. Int. Dairy J. 13:339-343.

International Dairy Federation (FIL-IDF). 2000. Whole milk: Determination of milk fat, protein and lactose content. Standard 141C:2000. IDF, Brussels, Belgium.

INRA. 1989. Ruminant Nutrition. Recommended allowances and feed tables. R. Jarrige, ed. Institut National de la Recherche Agronomique, Paris, France.

Jenkins, T. C. 1993. Lipid metabolism in the rumen. J. Dairy Sci. 76:3851-3863.
Kris-Etherton, P. M., and S. Yu. 1997. Individual fatty acid effects on plasma lipids and lipoproteins: Human studies. Am. J. Clin. Nutr. 65:1628S-1644S.

Littell, R. C., P. R. Henry, and C. B. Ammermann. 1998. Statistical analysis of repeated measures data using SAS procedures. J. Anim. Sci. 76:1216-1231.

Loor, J. J., A. Ferlay, A. Ollier, M. Doreau, and Y. Chilliard. 2005. Relationship among trans and conjugated fatty acids and bovine milk fat yield due to dietary concentrate and linseed oil. J. Dairy Sci. 88:726-740.

Mir, Z., L. A. Goonewardene, E. Okine, S. Jaegar, and H. D. Scheer. 1999. Effect of feeding canola oil on constituents, conjugated linoleic acid (CLA) and long chain fatty acids in goat milk. Small Rumin. Res. 33:137-143.

Mosley, E. E., and A. M. McGuire. 2003. The use of 13C labeled fatty acids to study milk fat synthesis in dairy cows. J. Dairy Sci. 87(Suppl. 1):206. (Abstr.)

Nudda, A., G. Battacone, R. Bencini, and G. Pulina. 2004. Nutrition and milk quality. Chapter 8. Pages 129-149 in Dairy Sheep Nutrition. G. Pulina, ed. CABI Publishing, Wallingford, UK.

Nudda, A., A. M. McGuire, G. Battacone, and G. Pulina. 2005. Seasonal variation in conjugated linoleic acid and vaccenic acid in milk fat of sheep and its transfer to cheese and ricotta. J. Dairy Sci. 88:1311-1319.

Palmquist, D. L., and T. C. Jenkins. 2003. Challenges with fats and fatty acid methods. J. Anim. Sci. 81:3250-3254.

Piperova, L. S., J. Sampugna, B. B. Teter, K. F. Kalscheur, M. P. Yurawecz, Y. Ku, K. M. Morehouse, and R. A. Erdman. 2002. Duodenal and milk trans octadecenoic acid and conjugated linoleic acid (CLA) isomers indicate that postabsorptive synthesis is the predominant source of $c i s$-9-containing CLA in lactating dairy cows. J. Nutr. 132:1235-1241.

Piperova, L. S., U. Moallem, B. B. Teter, J. Sampugna, M. P. Yurawecz, K. M. Morehouse, D. Luchini, and R. A. Erdman. 2004. Changes in milk fat in response to dietary supplementation with calcium salts of trans-18:1 or conjugated linoleic fatty acids in lactating dairy cows. J. Dairy Sci. 87:3836-3844.

Schmidely, P., and P. Morand-Fehr. 2004. Effects of intravenous infusion of trans-10, cis-12 or cis-9, trans-11 conjugated linoleic acid (CLA) on milk fat synthesis and composition in dairy goats during mid-lactation. S. Afr. J. Anim. Sci. 34(Suppl. 1):195-197.

Secchiari, P., M. Antongiovanni, M. Mele, A. Serra, A. Buccioni, G. Ferruzzi, F. Paletti, and F. Petacchi. 2003. Effect of kind of dietary fat on the quality of milk fat from Italian Friesian cows. Livest. Prod. Sci. 83:43-52.

Sessler, A. M., and J. M. Ntambi. 1998. Polyunsaturated fatty acid regulation of gene expression. J. Nutr. 128:923-926.

Van Soest, P. J., J. B. Robertson, and B. A. Lewis. 1991. Methods for dietary fiber, neutral detergent fiber, and non-starch polysaccharides in relation to animal nutrition. J. Dairy Sci. 74:35833597.

Wahle, K. W., S. D. Heys, and D. Rotondo. 2004. Conjugated linoleic acids: Are they beneficial or detrimental to health? Prog. Lipid Res. 43:553-587. 